\title{
Uma leitura do ethos discursivo nas capas das revistas de bordo
}

A reading of the discoursive ethos on the covers of in-flight magazines

Una lectura del ethos discursivo en las portadas de revistas en vuelo

Raquel Alves - Universidade Metodista de São Paulo | São Bernardo do Campo | SP | Brasil | E-mail: raquel@paragrafo9.com.br | Orcid: https://orcid.org/0000-0002-11859502

Antonio Roberto Chiachiri Filho - Universidade Metodista de São Paulo | São Paulo | SP / Brasil| / E- mail: archiachiri@gmail.com | Orcid: https://orcid.org/0000-00027595-8243

Resumo: A pesquisa investiga a manifestação do ethos discursivo nas capas das revistas Vamos/Latam e Gol dos anos 2017 e 2019. Tendo como base as proposições de Dominique Maingueneau, dentro do quadro teórico da análise do discurso, analisa-se a composição da cenografia, seus dizeres verbais e imagéticos, a fim de se identificar registros da construção de si das marcas Latam e Gol. Como resultado, a pesquisa constata nas referidas revistas de bordo, narrativas euforizadas de afeto, persuasão e engajamento social, que se imbricam com os objetivos estratégicos das marcas que representam, revelando vocalizações que vão do anfitrião ao ativista social.

Palavras-chave: Revista customizada. Ethos discursivo. Análise do discurso.

Abstract: The research aims to investigate the discursive ethos on Vamos/Latam and Gol magazines covers from 2017 and 2019. Based on Dominique Maingueneau propositions, in the theoretical discourse analysis, we studied how the scenarios were composed, the verbal and image speech, in order to identify how the brands Latam and Gol were built. As a result, the research has led to the conclusion that the narrative in both magazines carries affection, persuasion and social engagement that connects to the strategic goals of the brands they represent, revealing ethos modulations that go from the host to the social activist.

Keywords: Custom publishing. Ethos discourse. Discourse analysis.

Resumen: El estudio investiga la manifestación del ethos discursivo en las portadas de las revistas Vamos / Latam y Gol de 2017 y 2019. Con base en las proposiciones de Dominique Maingueneau, dentro del marco teórico del análisis del discurso, se analiza la composición de la escenografía, con palabras verbales e imaginería, para identificar registros de la autoconstrucción de las marcas Latam y Gol. Como resultado, la investigación encuentra en estas revistas de a bordo narraciones eufóricas de afecto, persuasión y compromiso social, que se mezclan con los objetivos estratégicos de las marcas que representan, revelando modulaciones de ethos desde el anfitrión hacia el activista social.

Palabras clave: Revista corporativa. Ethos discursivo. Análises del discurso.

- Recebido em: 23 nov. 2019 • Aprovado em: 09 jan. 2020 e-ISSN: 2177-5788 DOI: https://doi.org/10.22484/2177-5788.2020v46n1p59-85

Copyright @ 2020. Conteúdo de acesso aberto, distribuído sob os termos da Licença Internacional da Creative Commons-CC BY-NC-SA - Atribuição Não Comercial - Permite distribuição e reprodução, desde que atribuam os devido créditos à publicação, ao autor(es) e que licenciem as novas criações sob termos idênticos. 


\section{Introdução}

Revistas de bordo costumam ser relegadas no ambiente e nas pesquisas acadêmicas e há algumas razões para esse aparente desinteresse. Uma é a própria concepção híbrida dessas publicações que fundem, em proporções nem sempre equilibradas, o discurso publicitário com o discurso jornalístico. Como têm no mundo onírico das viagens, do estilo de vida e do escapismo seus principais pilares, tendem a ser entendidas como mero produto de entretenimento, portanto, praticamente não ensejam grande interesse por parte dos pesquisadores.

Ocorre que essas publicações merecem ser vistas também sob lentes mais críticas, que problematizem seu modo de ser, estar e de comunicar e seu potencial de produto cultural a serviço das marcas que representam. Uma porque as revistas de bordo têm provado seu poder de resiliência. Estão resistindo à crise do impresso de um modo geral, e mais particularmente, à crise que acomete as revistas e, mais especificamente ainda, a que se abate sobre as revistas de marca, as chamadas revistas customizadas. Enquanto estas estão quase desparecendo do composto de marketing das organizações, as revistas distribuídas gratuitamente nos aviões parecem bem longe de ter esgotado sua capacidade atrativa.

Foi a curiosidade acerca da história longeva das revistas de bordo que motivou a pesquisa Modo avião: uma reflexão sobre o ethos discursivo nas revistas Gol e Vamos/Latam, da qual deriva o presente artigo. Enquanto na dissertação foram analisadas edições inteiras, a partir da capa, editorial e matéria principal, aqui pretende-se focar apenas a capa pelo seu potencial imagético, que sintetiza o dizer de uma marca, na relação direta com o seu público.

Entender as demarcações do território habitado pelas revistas de marca é o primeiro passo para enquadrá-las na perspectiva de objeto de estudo. Sobre esse tema, Fischer (2013) desenvolveu a pesquisa mais definitiva a respeito dessas mídias. Na obra Revista customizada: O 
jornalismo a serviço das fontes, a pesquisadora faz menção ao fato dessa mídia ser preterida nos estudos acadêmicos.

\begin{abstract}
A bibliografia relacionada ao tema é igualmente escassa, restringindo-se a alguns poucos trabalhos acadêmicos, artigos e matérias publicadas em revistas especializadas em comunicação. Há ainda lacunas no que tange principalmente as etapas de sua produção, bem como os objetivos das organizações em publicá-las. (FISCHER, 2013, p. 6).
\end{abstract}

A escolha das duas revistas não é aleatória, ambas distribuem mais de 90 mil exemplares mensalmente e têm longa permanência no ar. A revista Gol decolou praticamente junto com a companhia, no ano 2002. A Vamos/Latam descende de projetos editoriais mantidos pela TAM no Brasil, como a revista TAM nas Nuvens, lançada em 2004. São, portanto, projetos editoriais maduros e que se colocam a serviço das duas empresas aéreas de maior representatividade no mercado brasileiro, a Latam e a Gol, pertencentes ao top 10 das melhores companhias aéreas da América do Sul, segundo ranking que consta em Skytrax (2018). Busca-se, nas concepções do ethos discursivo, como proposto por Dominique Maingueneau (2002; 2005; 2008; 2015a; 2015b), que dialoga com Amossy (2005), Patrick Charaudeau (2015; 2016) e Orlandi (2001；2009; 2015) compreender como as marcas modulam seus discursos nas capas de suas publicações de bordo, de modo a angariar simpatia e engajamento do leitor.

Esse percurso se faz com o entendimento das relações de consumo, o que recomenda refletir primeiramente sobre como as marcas ganharam autoridade e legitimidade para engendrar o próprio discurso, se colocando muitas vezes em pé de igualdade com as grandes editoras. Ao analisar o comportamento do hiperconsumidor no que chama de fase III da economia, Lipovetsky (2007) aprofunda a compreensão acerca da relação emocional que se estabelece entre os indivíduos e as mercadorias, muitas vezes alimentada por conteúdos de sua comunicação, como as campanhas de propaganda, a presença nas mídias digitais e no material impresso. Ingressamos, conforme Semprini (2010), na ambiência da sociedade de 
consumo, diante do fortalecimento e influência das marcas, sobre o modo como agimos, vivemos e pensamos em uma era pós-industrial.

A investigação parte da premissa de que um ato de linguagem se constitui em uma ação enunciativa que envolve também o que está implícito, quer seja o modo protagonistas com que se articulam e se relacionam na circunstância do discurso, entendendo que a relevância dessa pesquisa está em abrir um espaço para reflexão sobre as narrativas das marcas, num momento em que cada vez mais elas se esforçam para assumir a centralidade das histórias, se colocando como produtoras de conteúdo e de significados.

\section{0 gênero revista}

Infinitas possibilidades de práticas jornalísticas já se acomodaram no formato de uma revista. Como um repositório das experiências, crenças, modismos e ideologias de determinado período histórico, os magazines traduzem épocas, produzem memória, ajudam uma sociedade a se comunicar e a formar núcleos identitários, criando em torno de seus projetos editoriais comunidades com gostos e interesses comuns, uma vez que "a tendência de uma revista é a inclinação de seus leitores" (VILAS BOAS, 1996, p. 86).

Como quase tudo no campo do jornalismo, a revista foi resultado de avanços da tecnologia. Máquinas de impressão mais modernas permitiram melhor registro das imagens e papéis de melhor qualidade. Com novas possibilidades de impressão, a revista ganhou lugar entre o livro e o descartável jornal. A primeira publicação a utilizar a novidade foi a Erbauliche Monaths-Unterredungen (ou Edificantes Edições Mensais), que segundo Scalzo (2011) e Ali (2009), foi publicada entre 1663-1668, na Alemanha de Gutemberg, por um teólogo e poeta chamado Johann Rist, da cidade de Hamburgo, que sozinho dava conta de todo conteúdo. Foi a primeira revista de que se tem notícia. 
A virada para o século XIX foi definitiva para a consagração do estilo magazine. Com mais acesso às letras e mais dinheiro em circulação, a aristocracia europeia tem sede de consumo cultural. É o boom do estabelecimento das regras de gosto, estudadas por Veblen (1983), em que pontua as mudanças sociais a partir da relação das pessoas com seu modo de consumo.

As revistas ajudaram muito na difusão dos conceitos do que é belo, útil ou simplesmente necessário, contribuindo para legitimar relações de poder e visões de mundo. Linguagem e sociedade se amalgamam em uma, a ponto de tornar turvo o limite onde termina a linguagem e entra a ideologia. É o que nos remete ao pensamento de Foucault (2008), em relação às Formações Discursivas (FD), suportadas não apenas pelas condições de comunicação, mas também pelas estruturas sociais, como veremos adiante.

Em pesquisa minuciosa levada a efeito por Martins (2008) sobre a produção revisteira na São Paulo do início do século XX, a revista desponta como um disparador de tendências e de consolidação do pensamento.

\begin{abstract}
A revista era o instrumento eficaz de propagação de valores culturais, dado seu caráter de impresso do momento, condensado, ligeiro e de fácil consumo. Acrescenta-se a isso, por vezes uma aparência luxuosa, divulgando através da ilustração, propagandas e mensagens aliciadoras e pronto! Assim estava configurado o produto que subjugava corações e mentes, atingindo com presteza uma gama expressiva e diferenciada de leitores. Cada número publicado transformava-se em símbolo emblemático da transição vivida, expressando os conflitos do período e apresentando-se como porta-voz de múltiplas gerações. (MARTINS, 2008, p. 27).
\end{abstract}

A revista, conforme Martins (2008), é um documento da história, que permite não apenas inferências sobre o contexto em que foi gerada, como revela registros do estilo textual, iconográfico e extratextual em voga. Através da revista, o jornalismo ajudou a reforçar parâmetros da ascendente burguesia, ao mesmo tempo que avalizava a formação de um modus vivendi tipicamente capitalista. É fato que narrativas temperadas com mais ou menos subjetividade têm acompanhado o homem desde REU, Sorocaba, SP, v. 46, n. 1, p. $59-85$, jun. 2020 
tempos imemoriais, mas em se tratando do jornalismo como um processo industrial, é a influência do Novo Jornalismo americano, que emergiu num contexto de transformação política e social, prestou enorme contribuição para a difusão de histórias com alma e sabor, sem abrir mão da informação crua e real, o que "mudou o modo de pensar, perceber e de sentir o mundo" (VILAS BOAS, 1996, p. 105).

Perceber essa evolução na linguagem e o modo como os estilos imagéticos e de escrita se acomodaram a seus suportes é importante para compreender o uso que as marcas farão dessas narrativas com o passar do tempo, emprestando do jornalismo o ferramental e a credibilidade para contar histórias envolventes e para compor seus discursos e seu ethos, de acordo com o perfil do leitor com quem pretendem se relacionar. Ali (2009, p. 32) destaca a relação entre o discurso e seu receptor, espaço em que se dá o que ela chama de "contrato implícito": "Prometo que se você ler esta revista, edição após edição, encontrará à sua disposição o que é importante para você e do seu interesse, vai saber o que quer saber, o que precisava saber e até o que não precisava". Tavares e Schwaab (2013) vão além e concluem que o leitor entende esse contrato em uma perspectiva de tempo.

\footnotetext{
É preciso considerar que, ao tomar nas mãos um exemplar, o leitor não tem apenas aquela edição diante de si, mas tem as referências de um passado, no qual se inserem os números anteriores; e um futuro, uma sobrevida própria da permanência da revista como documento, além da sequência de números posteriores a serem publicados. Os conteúdos, por mais ligados que estejam a fatos ocorridos em datas próximas à publicação, como no caso das newmagazines semanais, discursivamente trazem laços com questões próprias daquela revista, conformações esperadas para aquele título e para cada editoria ou seção. (TAVARES; SCHWAAB, 2013, p. 135).
}

Interessante observar que quando a revista é pensada em função do leitor e de seu repertório de gostos, crenças, experiências e estilo de vida, o receptor assume integralmente a condição de consumidor. É enquadrado em um certo perfil que homogeneiza todos os leitores. No nascedouro de todo projeto editorial e comercial de revista, observa-se o critério de 
estabelecer o lugar da escuta, uma tentativa de antecipação de sua adesão ao discurso.

\title{
3 O leitor e a marca
}

Para mapear o ethos institucional de uma marca, na forma como se manifesta na cena de enunciação, o analista deve identificar, nos mecanismos narrativos do texto, a voz da marca, a tonalidade que ela manifesta para projetar a autoimagem ideal. Há que se considerar prioritariamente as condições de produção do discurso, uma vez que os sujeitos ativos no fazer da revista ocupam uma posição em uma determinada formação social e se colocam em uma condição de convencimento do auditório.

Durante uma viagem de avião, ao folhear a revista da companhia que o transporta, o passageiro/leitor já está imerso no universo da marca. A revista de bordo e seu conteúdo ampliam essa proximidade. Se fosse apenas para entreter o leitor, bastaria às companhias aéreas disponibilizar qualquer revista de banca, avalizada por uma editora de competência reconhecida, e a missão estaria cumprida. É evidente que só isso não basta. Estampar o próprio logotipo na capa e construir uma simbologia de marca em torno das narrativas é parte da experiência de consumo e justifica todo o investimento que as marcas fazem nesse tipo de publicação. Perez (2016), contribui para a compreensão dessa experiência entre a marca, seu conteúdo simbólico e o consumidor:

\begin{abstract}
A marca comunica-se com os consumidores por meio dos sentidos e das emoções que é capaz de gerar e os "templos" que as abrigam contribuem para reforçar essas sensações. Essa construção perceptiva é possível por meio de nossas experiências sensoriais. Nossos sentidos são a "porta de entrada" das nossas percepções, são condutores de significados que se constroem no cérebro e tomam a nossa consciência e corpo. (PEREZ, 2016, p. 122).
\end{abstract}

Perceber como esse estado emocional é ativado é parte importante deste trabalho, na medida em que dialoga diretamente com a construção 
do ethos. A leitura que aqui se busca parte da premissa de que o ethos discursivo só se constrói no momento da enunciação. Por uma maneira de dizer que remete a uma maneira de ser, o enunciador se torna fiador do discurso no qual ele está inscrito. Ali ele está autorizado pelos efeitos de seu lugar institucional, incumbido de mediar a relação com outros discursos dos quais se alimenta.

A revista de bordo é, portanto, a cena genérica de uma dada formação discursiva e seu conjunto enunciativo a coloca no limite entre processos informativos e persuasivos. Ideologicamente filia-se à cena englobante do discurso organizacional, já que representa uma marca do mercado de consumo. Em termos genéricos, na concepção de Maingueneau (2015a, p. 122), busca nas competências específicas da prática jornalística uma moldura para o seu fazer. Quanto à cenografia, noção que se apoia na ideia de que o enunciado, por meio da enunciação, organiza a situação a partir da qual pretende enunciar, é o que contribui para viabilizar a adesão do destinatário, sendo constituída no próprio texto, de modo poético, doce, professoral, profético, amigável. Conforme Maingueneau (2008, 2015a, 2015b) e Amossy (2005) são os conteúdos pelos quais se valida a cena de enunciação e o próprio ethos.

O conceito de modelação do ethos requer condições para sua emergência, levando em conta quem fala o que, de onde fala, o que intenta expor sobre si e como é de fato recebido e compreendido pelo interlocutor. O ethos efetivo, portanto, se constitui no efeito de sentido que mobiliza o enunciatário quando o ethos por ele preconcebido encontra o ethos discursivo (dito e mostrado). Esse tensionamento tanto pode confirmar algumas crenças que o enunciatário já tinha quanto acrescentar outras. Sobre ethos dito e ethos mostrado, Maingueneau (2008, p. 71) aponta as diferenças: "o ethos dito vai além da referência direta do enunciado à sua própria pessoa ou a sua própria maneira de enunciar ('eu sou um homem simples', 'eu Ihes falo como um amigo' etc.)". 
A instância subjetiva que se manifesta no discurso enverga também traços psicológicos, além de uma corporalidade e uma vocalidade, que abraçam todo tipo de texto. Maingueneau (2008, p. 145-146) prefere falar em "tom", que contempla tanto o escrito quanto o falado. Ele atribui essas características ao "fiador" do discurso, cujas "ideias" revelam uma maneira de dizer, que também é uma maneira de ser. Fala também sobre o "mundo ético" deste enunciador e o universo de comportamentos e representações estereotipados associados a ele.

\section{A voz das marcas}

Nosso interesse acadêmico na escolha do corpus se deu em função de as duas revistas (Gol e Vamos/Latam) representarem as marcas líderes do setor de aviação comercial no Brasil. O recorte considera as edições distribuídas nos meses de janeiro e julho, apontados em sucessivas pesquisas da Associação Brasileira das Empresas Aéreas (2019), como os meses de maior fluxo de passageiros. Para contemplar a questão da maturidade e estabilidade dos dois projetos editoriais, escolhemos edições com intervalo de dois anos. São, portanto, oito edições, quatro da Revista Gol e quatro de Vamos/Latam, dos meses janeiro e julho, anos 2017 e 2019. A razão de se trabalhar com o texto da capa tem a ver com o fato de sua importância em qualquer projeto editorial impresso. É o que baliza editores, jornalistas, fotógrafos e leitores. É a porta de entrada para que se firme o contrato de comunicação, previsto por Charaudeau (2015). Em um estudo sobre o poder de atratividade das capas de revistas, Vaz, Trindade e Costa (2013, p. 221) pontuam: "Sua concepção prevê alguém que, em um simples vislumbre, se apaixone por ela e atribua-lhe sentidos. Sendo assim não podemos falar em capa de revista sem considerar esse sujeito que se relaciona com ela e que lhe atribui vida".

A capa é um dos elementos fundantes do formato revista e da identidade dos projetos editoriais que escolhem esse suporte, definidora daquilo que se chama conceito da publicação. Para proceder a análise das 
capas vamos considerá-las como um texto, que abarca aspectos verbais e não verbais e que representa outros textos a serem descortinados com um simples folhear de páginas e ainda estabelecem relação com uma coleção de outros textos, colocados numa perspectiva de tempo e representados pelas edições anteriores e posteriores. Ao contextualizar a função da capa para o sucesso de uma revista, Scalzo (2011) oferece uma trajetória de análise bastante apropriada, que coloca a capa como um fator de identidade da revista. É o principal elemento a ligar uma determinada edição ao conjunto dos enunciados do qual ela é parte e representa.

Em qualquer situação, uma boa imagem será sempre importante e é ela o primeiro elemento que merecerá atenção do leitor. O logotipo da revista também é fundamental, principalmente quando ela é conhecida e já detém uma imagem de credibilidade junto ao público. (SCALZO, 2011, p. 63).

Cabe ressaltar que a revista Gol está no recorte deste corpus em dois momentos distintos. Na edição de janeiro de 2017 (Figura 1) expressa o antigo projeto gráfico e editorial, com um padrão de capa que já estava em vias de ser superado, o que aconteceu cinco edições depois. 
Figura 1 - Capa expressa o antigo projeto gráfico e editorial

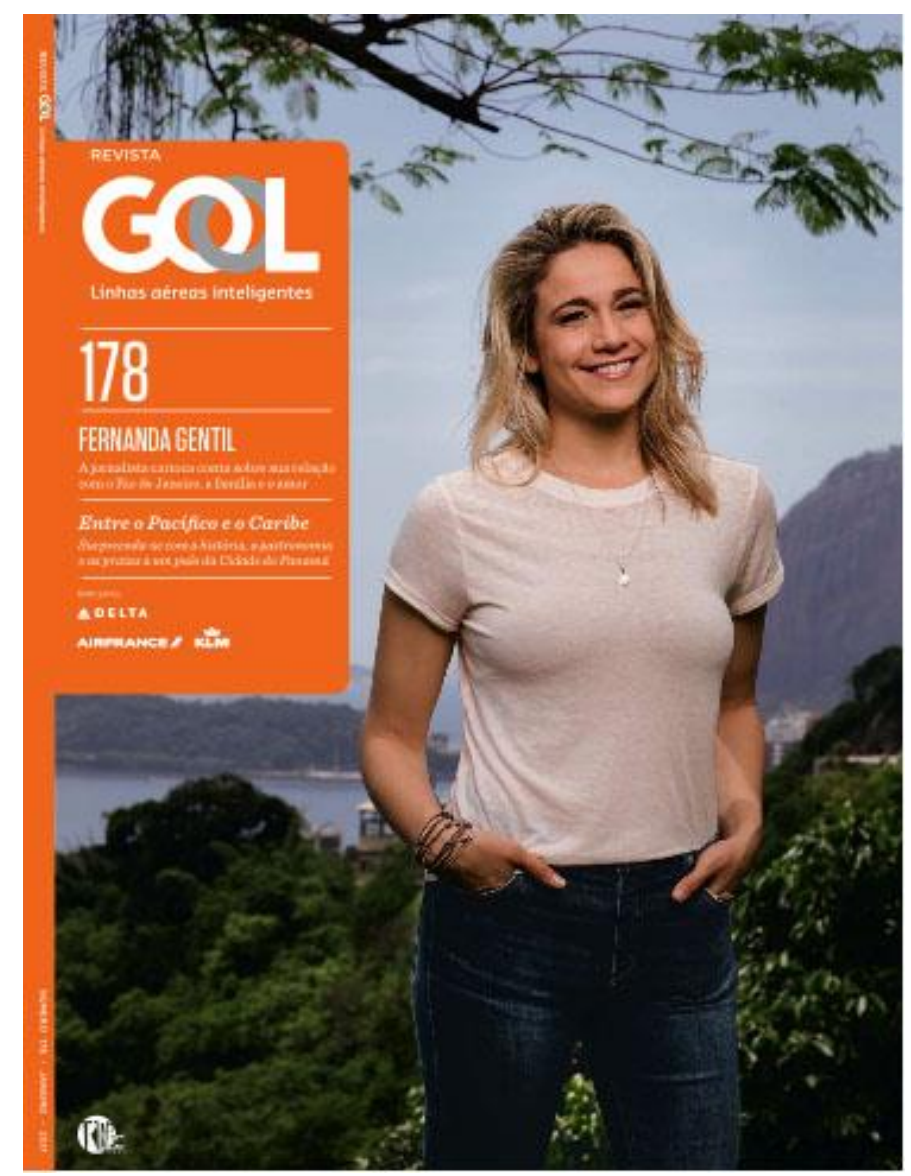

Fonte: GOL Linhas Aéreas. São Paulo: Trip Editora e Propaganda S/A, n. 178, jan. 2017.

Já as edições que representam a configuração atual da revista Gol, acompanhada do slogan Nova Gol, novos tempos no ar estampam sempre personagens que atuam como avalistas de um discurso a respeito da temática convocada para a edição. Esse padrão vem desde a edição 183, de junho de 2017, apresentando o tema das novas famílias, protagonizado pelo estilista Alexandre Herchcovitch, o marido, Fábio de Souza, e os filhos (Figura 2). 
Figura 2 - Capa protagonizado pelo estilista Alexandre Herchcovitch, o marido, Fábio de Souza, e os filhos.

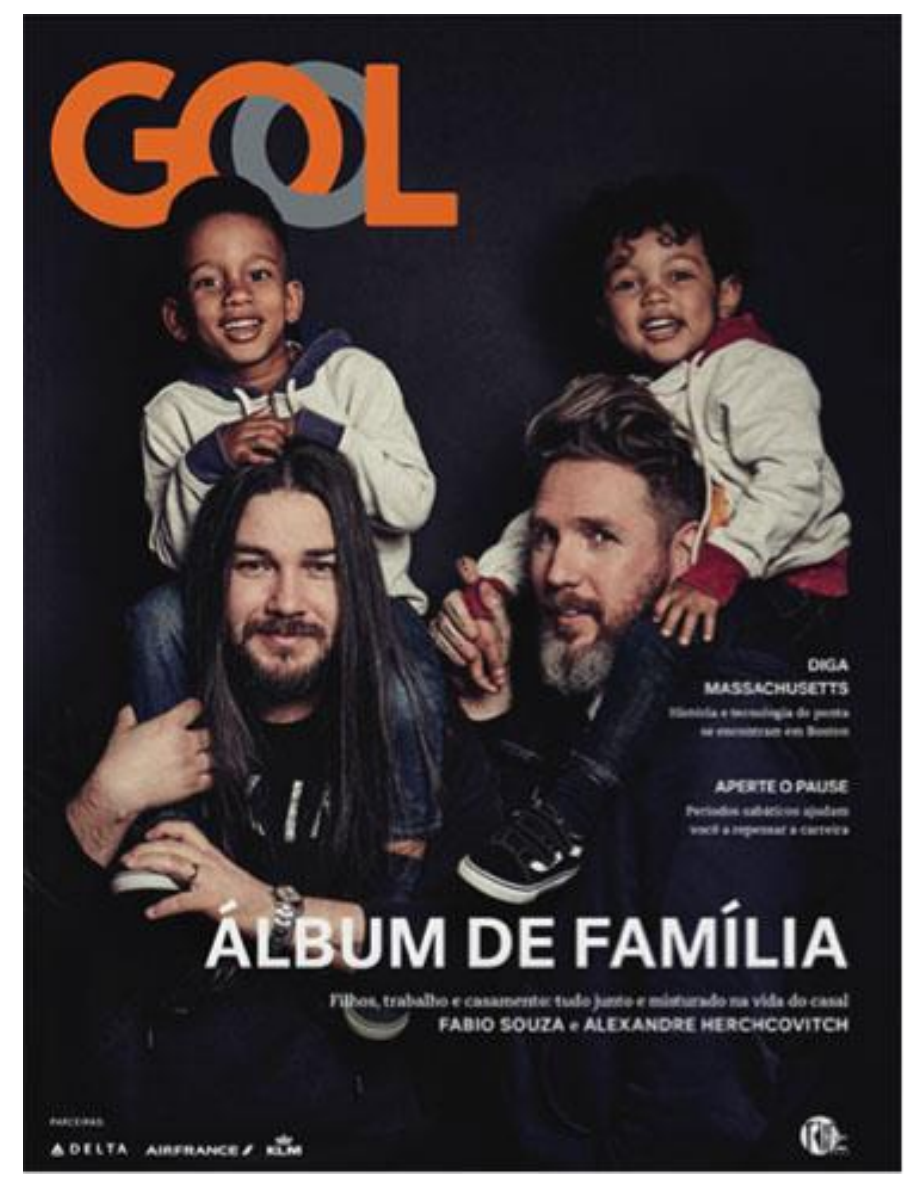

Fonte: GOL Linhas Aéreas. São Paulo: Trip Editora e Propaganda S/A, n. 183, jun. 2017. $156 \mathrm{p}$.

O personagem, nem sempre reconhecível pelo público, e seu tema estão a serviço dos "temas urgentes" ou "mundo mais igualitário" proposto na missão editorial da revista, com o qual a empresa quer identificar-se.

Também é padrão da revista estampar uma única chamada de capa, que exprime a relação do personagem com o tema proposto. Até aqui tratamos apenas as linhas guias que apoiam o conteúdo das capas. Padrões mais ou menos estanques que funcionam como definidores da identidade editorial, ao mesmo tempo em que promovem o encontro do enunciado com o discurso da marca e com os elementos da construção da ideia de si, ou seja, seu ethos discursivo. 
Partimos dessa conceituação genérica para, em seguida, colocarmos cada capa em uma perspectiva singular de análise. Fazemos essa convocação por ordem de data, a fim de que possamos identificar traços de construção ou desconstruções editoriais no percurso. Começando pela Gol, edição 178, de janeiro de 2017 (Figura 1), a única deste corpus que reflete a antiga conformação editorial da revista.

Convocada para colocar sua corporalidade a serviço do ethos da marca, a jornalista e apresentadora Fernanda Gentil, num retrato ao ar livre, sorriso no rosto, vestuário básico, quase minimalista, evoca estereótipos de sucesso, independência e liberdade. Ela sorri para o leitor, em meio a uma paisagem de sua cidade, o Rio de Janeiro. Na época em que surgiu na capa da revista, Gentil havia assumido havia pouco tempo uma relação homoafetiva, portando um discurso de apropriação de interesse da marca, como veremos adiante. A chamada é "A jornalista carioca conta sobre a sua relação com o Rio de Janeiro, a família e o amor". Temos aí um conjunto ou uma atitude discursiva mobilizadora da afetividade do intérprete.

Ao mesmo tempo em que o discurso se constrói à volta de um rosto reconhecível, o ethos sutilmente quer transferir para o enunciador, a qualidade de uma organização aberta, disposta a discutir as temáticas de seu tempo. A relação com a pessoa do mesmo sexo está implícita na chamada. Não é claramente expressa, mas o leitor entende por que já detém a informação e subentende a função sintática do amor e família. Porém, os cuidados cenográficos evitam abordar o tema com todas as letras. De modo que o não-dito é interpretável pela maioria dos leitores.

$\mathrm{Na}$ segunda chamada, com menos destaque em relação ao tema principal da edição (a apresentadora e jornalista Fernanda Gentil), a revista Gol "pisa", enfim, na sua praia, o turismo: Entre o Pacífico e o Caribe, surpreenda-se com a história, a gastronomia e as praias a um pulo da Cidade do Panamá. O enunciador, como quem convida o leitor para um passeio recorre aos clichês das revistas de turismo para tratar de um dos 
destino da companhia aérea, o Panamá e mostra desenvoltura lexical para visitar um tema sobre o qual tem o domínio: as viagens, recorrendo a lugares-comuns da língua - a um pulo - para transmitir a facilidade de estar lá. Ou a facilidade que o locutor the assegura de acessar o destino e seus encantos.

Figura 3 - Capa a bordo de seu novo projeto editorial, alinhado com o slogan, Nova Gol, novos tempos no ar.

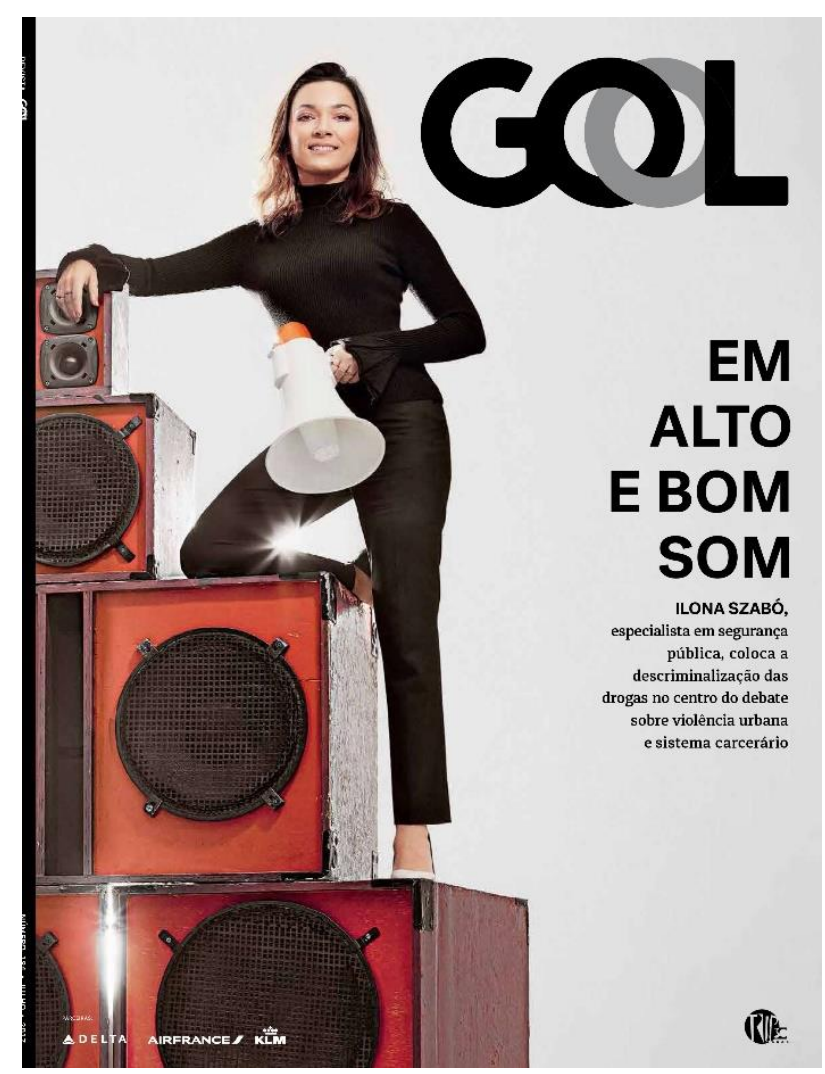

Fonte: GOL Linhas Aéreas. São Paulo: Trip Editora e Propaganda S/A, n. 184, jul. 2017. $81 \mathrm{p}$.

O ano é 2017 e a revista Gol já está a bordo de seu novo projeto editorial, alinhado com o slogan, Nova Gol, novos tempos no ar. Para marcar a mudança, a revista reorganiza suas estratégias discursivas. Esforça-se para construir um ethos rejuvenescido, reveste-se de autoridade para falar de temas distantes do mundo viagens-turismo-pessoas famosas. Esse enfoque passa ao segundo plano. Na capa (Figura 3), um rosto não famoso é retratado no alto de uma pilha de caixas de som, megafone na 
mão com a seguinte chamada: Em alto e bom som. Ilona Szabó, especialista em segurança pública, coloca a descriminalização das drogas no centro do debate sobre violência urbana e sistema carcerário.

O modo de dizer: "em alto e bom som", é um lugar-comum, propõe interdiscursividade com uma expressão de saber popular, é incorporado ao texto em sua própria intencionalidade: gritar para todo mundo ouvir. $\mathrm{O}$ fato de uma revista de bordo eleger um personagem que porta um tema sensível (legalização das drogas), porém, se faz em uma cenografia cuidadosamente preparada, que evoca o ethos de um ativismo (sugerido pela cena, com megafone e caixas de som) comportado e controlado.

Figura 4 - Capa com a filósofa Viviane Mosé.

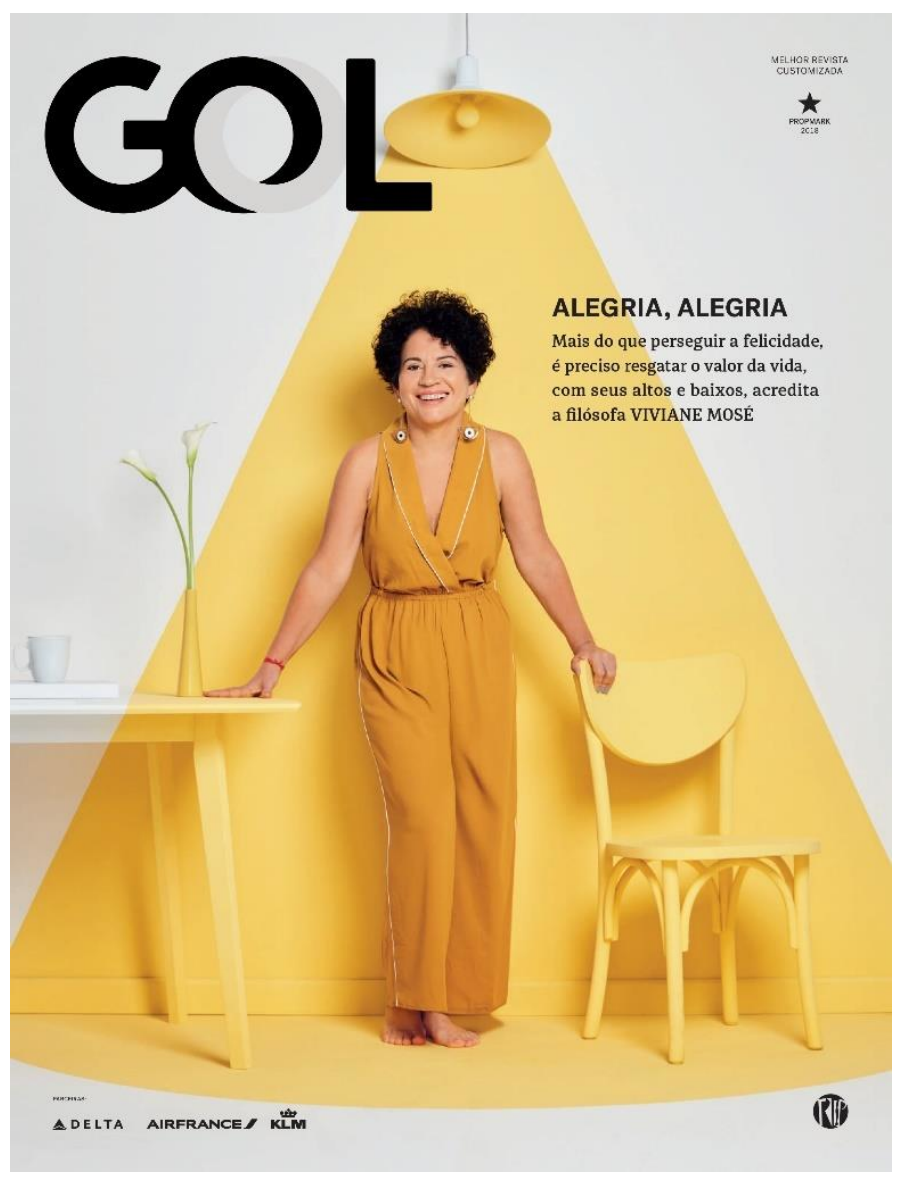

Fonte: GOL Linhas Aéreas. São Paulo: Trip Editora e Propaganda S/A, n. 202, jan. 2019. $61 \mathrm{p}$. 
Na edição 203, de janeiro de 2019 (Figura 4), a revista Gol aporta nas aeronaves com a filósofa Viviane Mosé na capa. Chegamos à terceira edição de sua nova configuração sob a perspectiva analítica deste estudo e já se nota um certo padrão cenográfico em suas capas.

Apesar do intervalo de seis meses entre as edições estudadas aqui, uma certa unidade se mantém: são três capas protagonizadas por mulheres, nenhuma repetindo o que é um estereótipo do gênero revista: os atributos físicos. Vestem roupas discretas, usam pouca maquiagem e estão imersas em textos visuais que se imbricam no discurso. Uma jornalista, uma antropóloga e uma filósofa, o que denota o objetivo de construir uma coesão discursiva. Voltando o foco para a capa com Viviane Mosé, sobre a qual dedicamos a observação discursiva, a cena genérica deixa clara a narrativa visual em consonância com o texto verbal, colocando a filósofa no centro da página sob o foco de um recorte amarelo, imitando um facho de luz, que desce de uma luminária até a mancha inferior da página.

O amarelo remete diretamente à luz, ao sol, é parte também de um campo semântico constituído pela bandeira brasileira. A cena é quase uma dramaturgia construída para envolver o leitor e mobilizar suas capacidades interpretativas. Sob o título: Alegria, alegria. Mais do que perceber a felicidade, é preciso resgatar o valor da vida com seus altos e baixos, acredita a filósofa Viviane Mosé, a revista Gol se coloca na discussão sobre felicidade, tema recorrente na mídia e nos grupos de internet, disposta a cumprir uma promessa embutida na sua missão editorial, os tais temas urgentes. 
Figura 5 - Capa "um rapper e um juiz contra a injustiça social"

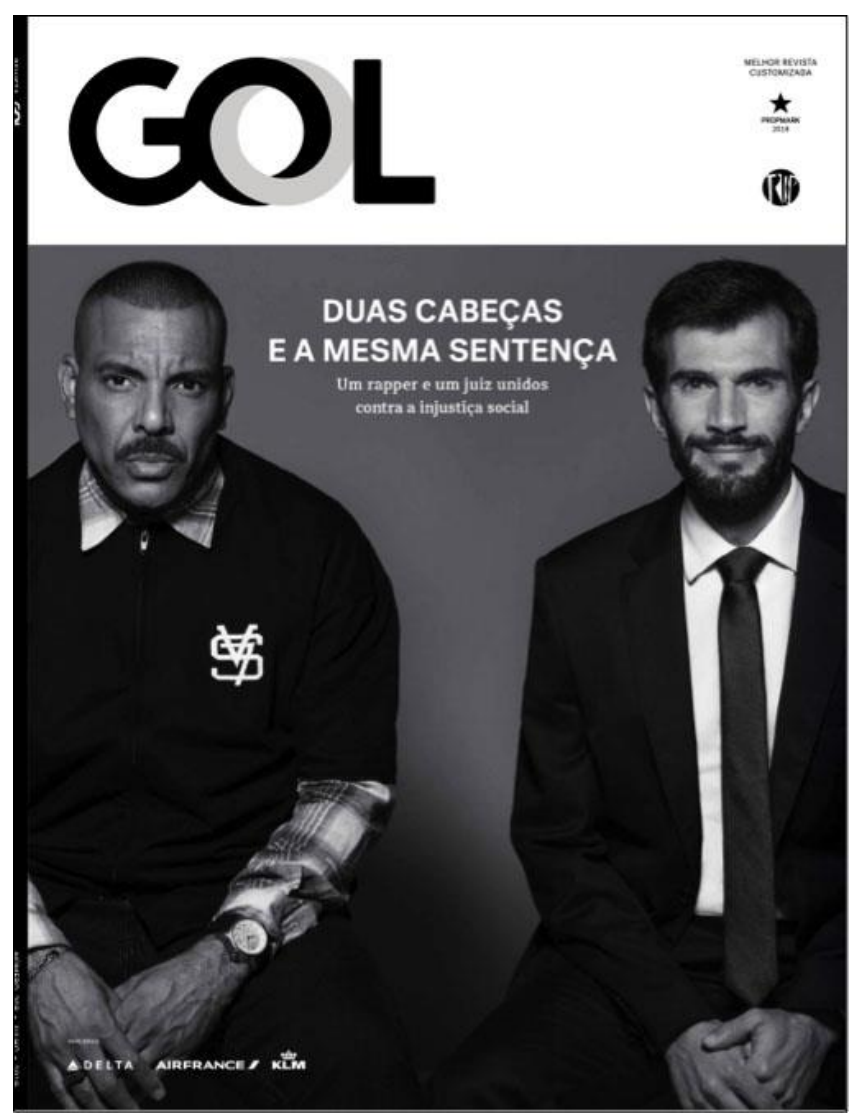

Fonte: GOL Linhas Aéreas. São Paulo: Trip Editora e Propaganda S/A, n. 208, jul. 2019.

A troca semântica, pelo estranhamento que propõe num primeiro momento, pode suscitar a curiosidade. É reveladora, ao mesmo tempo, de uma habilidade especial do falante em retorcer as palavras para propor um novo sentido, que se amplia quando incorporado ao todo da cenografia. Lá estão, portanto, em imagens, as tais "duas cabeças", expressando seus respectivos mundos éticos. O complemento do texto apresenta os personagens, ainda sem os nomes: "um rapper e um juiz contra a injustiça social". O efeito de sentido pode ser percebido já no modo como ambos estão vestidos e a expressão com a qual se dirigem ao leitor, indicativos de suas identidades sociais. A cenografia se reveste de um caráter teatral, uma vez que a construção do enunciado coloca em ação dois personagens que atenderam aos direcionais de pose, figurino e luz propostos pela revista. 0 preto e branco acentuam o tom sério. Sem o colorido, que a maioria das revistas de variedades costuma envergar na capa, o ethos discursivo impõe REU, Sorocaba, SP, v. 46, n. 1, p. $59-85$, jun. 2020 
economia, contrição, afinal se pretende abordar um tema que preocupa e de alguma forma mobiliza afetos do enunciatário: a injustiça social.

Figura 6 - Capa revista Vamos/Latam, n. 09, jan. 2017

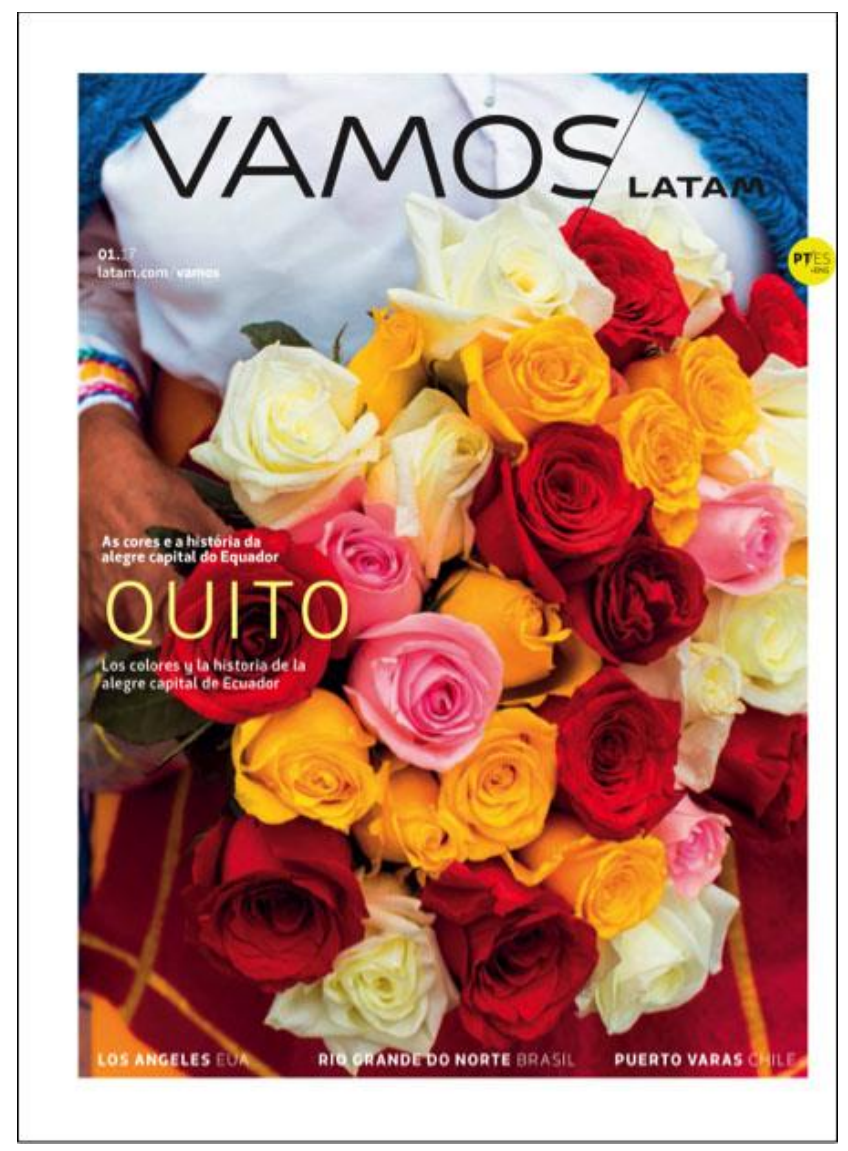

Fonte: VAMOS/LATAM. São Paulo: New Content, n. 9, jan. 2017. 172 p.

O padrão da capa da Vamos/Latam mantém o logotipo da revista no alto da página, aplicado sobre a foto que preenche a mancha total da página, em geral, paisagens, cenas de cidades e atrações turísticas de destinos da América Latina, expressando uma condição prevista na construção de si da marca, que é ser referência em turismo na América Latina. A grafia Latam é a mesma da logomarca da companhia aérea, mas o Vamos/ que a precede tenta atribuir à revista um nome e um ethos próprio à publicação, derivado da "marca-mãe", mas com certa autonomia, avalizando uma identidade editorial. Vamos sugere um convite, engendrando um valor da marca que é dar ao enunciatário acesso a um 
mundo perfeito de paisagens irretocáveis e pleno de felicidade. Seguramente uma construção de si que a marca coloca no discurso, e que está prevista na missão da revista em expressões como inspirar, ajudar, explorar, contidas na missão editorial. E porque usada em primeira pessoa (nós), coloca já o enunciatário em sua construção. Vamos tem o mesmo sentido em espanhol, é também carregada de otimismo (vamos a la playa, vamos a conocer...) e prevê a condição plural, a soma eu+tu, ou, como sugere Fiorin (2016, p. 79), um tu genérico, que tem por função "pessoalizar enunciados impessoais". Há uma chamada principal que informa sobre a imagem da capa e três chamadas secundárias, destacando os destinos de viagens abordados no miolo da edição.

A $9^{a}$ edição de Vamos/Latam (Figura 6), reforça seu padrão de capa com mais um destino turístico, Quito, no Equador. Um maço de rosas de várias cores ocupa o primeiro plano e quase a dimensão toda da página. Um retrato sem rosto, acentua uma certa impessoalidade. A pessoa está na imagem, avista-se o colo, a camisa abotoada, a mão direita, mas foco se fecha sobre o colorido das rosas que ela carrega e parece oferecer ao leitor. Numa explosão de cores que se aproxima dos tons da bandeira equatoriana, a cenografia sugere um mundo de aromas e belezas no decorrer das páginas seguintes e deixa pegadas de um distanciamento. O dizer de si se reveste de um convite para que o destinatário adote o mesmo ponto de vista para apreciar o que é mostrado. São pegadas de um ethos que propõe o escapismo, sob o enunciado: "As cores e a história da alegre capital do Equador". O ethos da marca Latam, como facilitadora de viagens, é reforçado nas outras três chamadas, selecionadas para a capa. Na verdade, três destinos de viagem, sem adição de qualquer verbo ou adjetivo: Los Angeles/EUA, Rio Grande do Norte/Brasil e Puerto Varas/Chile. Um locutor que atua como um anfitrião, apela para o imaginário do interlocutor, afinal, "se as cores e as formas são assim tão intensas, imagine o que é estar lá", parece convidar. A imagem de si nesse discurso multicolorido é a de um conhecedor dos saberes da vida hedonista. 
Figura 7 - Capa revista Vamos/Latam

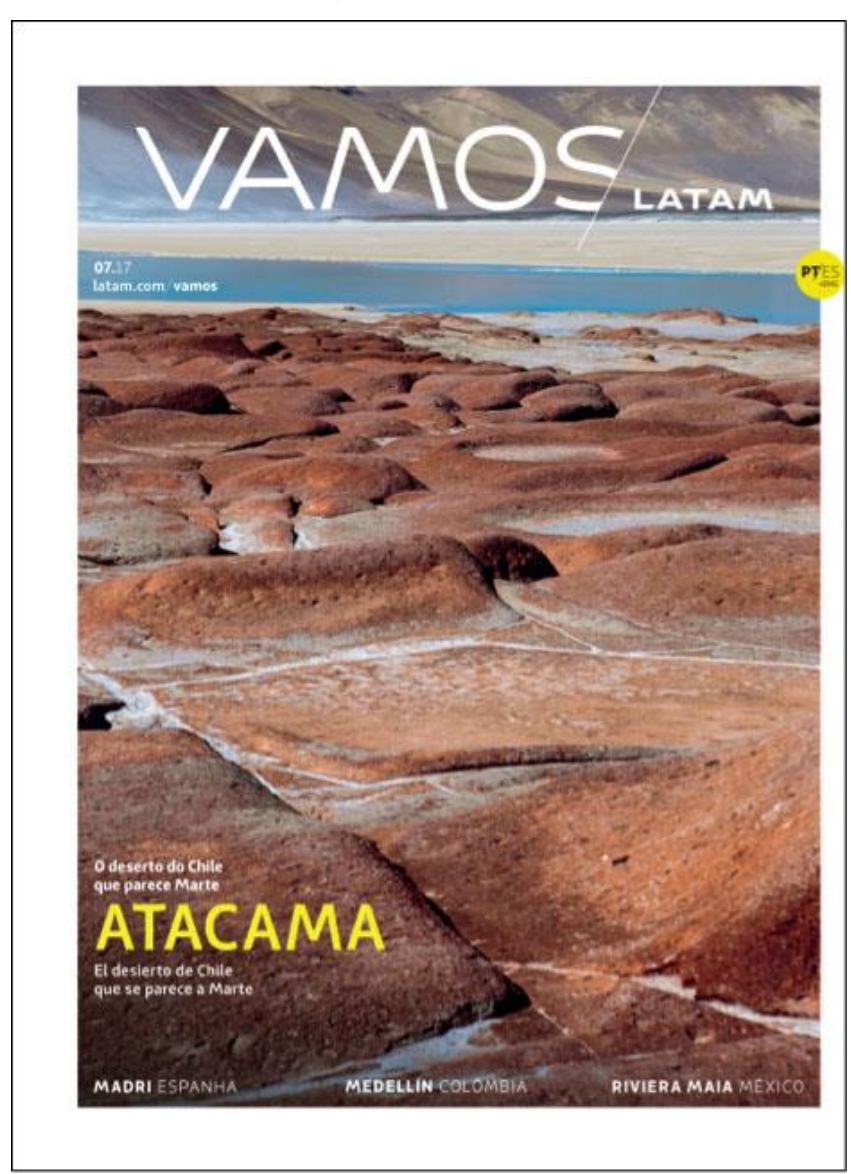

Fonte: VAMOS/LATAM. São Paulo: New Content, n. 15, jul. 2017. 180 p.

Vamos/Latam chega à edição 15 (Figura 7) com mais um destino turístico estampando a capa. É mês de férias escolares, de aviões cheios e a recomendação da revista é uma paisagem chilena, o deserto do Atacama, o que reforça o ethos discursivo de anfitrião. Anfitrião porque conhece a cena englobante (o turismo), à qual pretende dar acesso ao enunciatário, e sobretudo porque tem profundo conhecimento do país e do lugar sugeridos na capa como destino para uma viagem de férias. O fiador revela legitimidade para tratar do tema, uma vez que a Latam, como já se disse, é a fusão da Lan Chile com a TAM, sendo que o "sotaque" chileno é bastante evidente na revista como um todo e nesta edição em especial. Sob a chamada: "O deserto do Chile que parece Marte, Atacama", a imagem revela a aridez crua do deserto. Uma imagem genérica, aberta, sem um 
ponto definido. Não há movimento, não há vida, não há um único recurso cênico em primeiro plano ou servindo de moldura à paisagem seca, terrosa.

A impressão de distanciamento tende a remeter o enunciatário a uma posição remota, reforça a impessoalidade, um ethos que parece se ausentar para se fazer presente. Sobre a imagem de aridez do deserto, mais três chamadas oferecem destinos que estão no miolo da edição: Madri/Espanha, Medellín/Colômbia e Riviera Maia/México.

Figura 8 - Capa revista Vamos/Latam, n. 33, jan. 2019

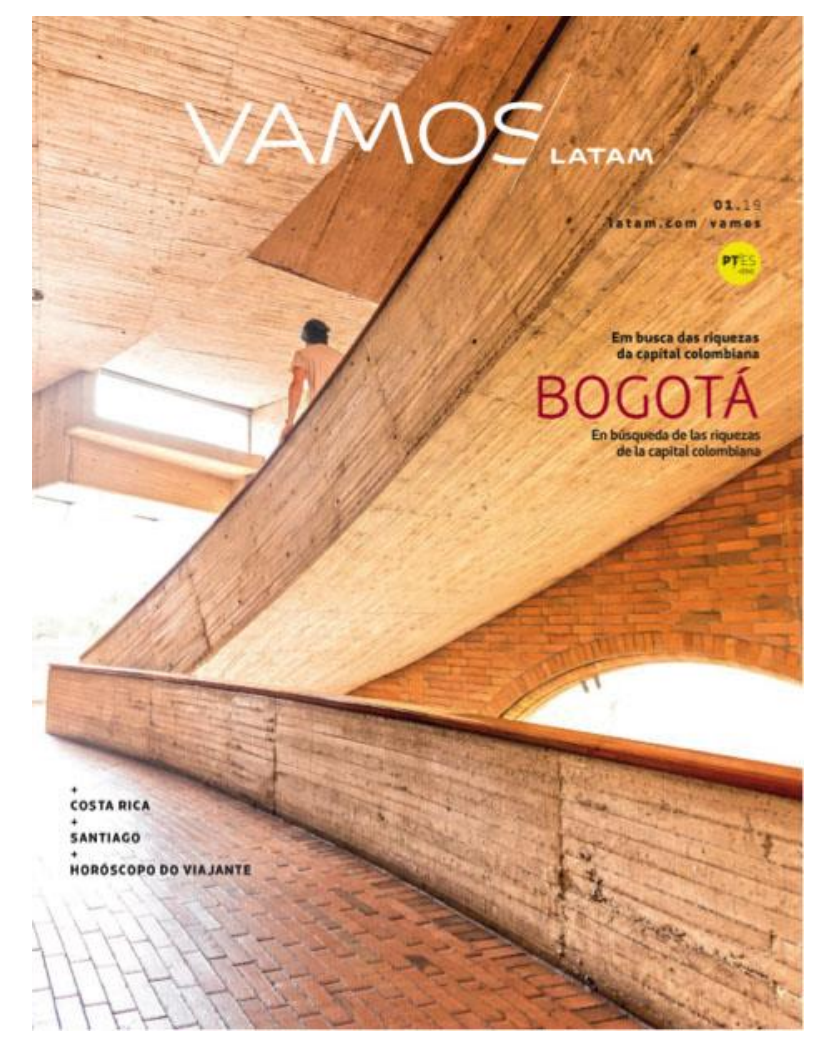

Fonte: VAMOS/LATAM. São Paulo: New Content, n. 33, jan. 2019. 164 p.

Sobre concreto e tijolo é construído o discurso quase monocromático da capa da edição de janeiro da revista Vamos/Latam (Figura 8), em tons que vão do bege ao alaranjado. A imagem mostra o que parece ser o interior de um edifício, sobreposição de várias perspectivas geométricas, planos mais altos, plataformas de acesso, com recortes que inundam a cena da luz vinda do lado de fora. Há uma pessoa no centro da imagem, de costas, aparentemente flagrada por acidente ou por um capricho do fotógrafo, para 
acrescentar um ponto focal de humanidade na paisagem fria. O apelo é o design, a arquitetura, num recorte de apelo estético interessante, mas que não conta tudo e amplia a percepção a respeito de um anfitrião distante. $A$ chamada propõe uma ideia vaga de algum lugar representativo de Bogotá, sugerido o texto verbal: Em busca das riquezas da capital colombiana, Bogotá.

A narrativa busca conquistar a adesão do leitor pelos estereótipos comuns nos discursos do trade de turismo. Ao mesmo tempo distrai o leitor no momento da viagem, busca seduzi-lo a explorar um novo destino, que a Latam conhece como a palma da mão. Mais três chamadas menores, separadas verticalmente por um sinal de + apontam os outros temas que são abordados na edição: Costa Rica, Santiago e Horóscopo do Viajante. Ressalta mais uma vez o distanciamento, representado pela economia de referências, o que pode também ser um desejo do locutor de se fazer menos óbvio e mais enigmático.

$\mathrm{Na}$ edição de julho de 2019 (Figura 9), mês de férias e de Jogos Panamericanos, a revista Vamos/Latam repete na capa o padrão discursivo que é marca da sua identidade. A imagem única mostra um destino na América do Sul, no caso Lima, capital do Peru. A semelhança com as manifestações discursivas anteriores é que a fotografia nunca é um cartãopostal reconhecível, mas uma paisagem prosaica, sem um traço identitário marcante. 
Figura 9 - Capa revista Vamos/Latam, n. 39, jul. 2019

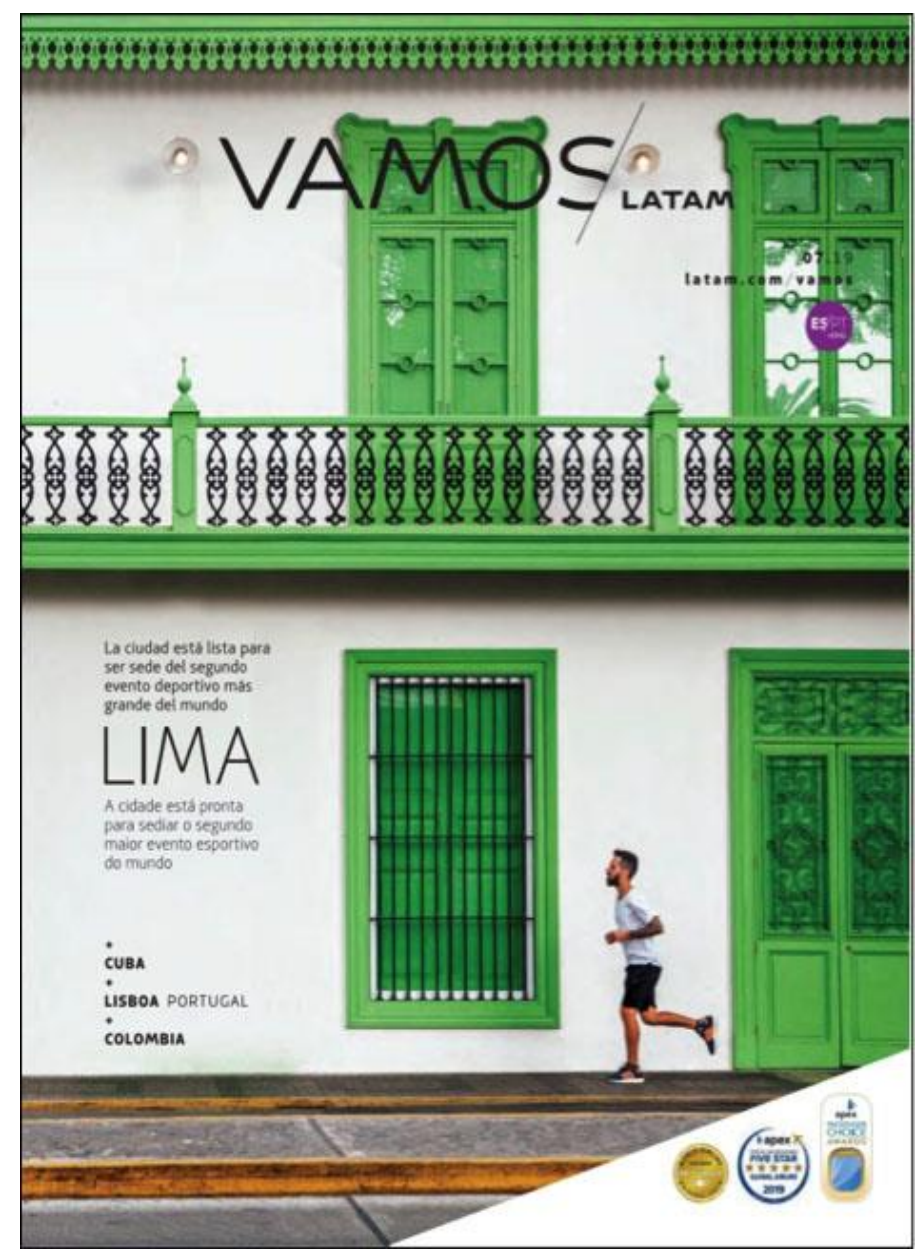

Fonte: VAMOS/LATAM. São Paulo: New Content, n. 39, jul. 2019. 156 p.

O casario de estilo colonial, janelas verdes, fotografado em Lima, é bem parecido com muitos outros que habitam cidades como Salvador, Buenos Aires ou Cidade do México. Nada de muito singular, mas pela repetição, edição após edição, configura-se como estratégia para "oferecer" ao leitor o ethos de um anfitrião que prega e pratica o turismo menos óbvio e, portanto, mais exclusivo. Só um locutor nativo, ou com profunda intimidade com a região fotografada é capaz de capturar a cidade em ângulos que não estão nos sites ou folhetos de propaganda. Também se repete, em relação às capas investigadas neste estudo, a pessoa sem rosto, o figurante ou passante, que interage com a paisagem, quase que por acidente. Aqui, o corredor empresta seu movimento à imagem e acrescenta um pouco de humanidade à capa da revista. A diferença, em relação às 
capas anteriores aqui analisadas, são os três grafismos de prêmios, outorgados à Latam em 2019 por associações de fomento ao turismo, invadindo o canto direito inferior da imagem, como se fosse uma dobra da página, evidenciando os traços de vaidade no ethos discursivo.

A chamada de capa, "A cidade está pronta para sediar o segundo maior evento esportivo do mundo, Lima", por coerções do próprio dispositivo, não menciona o nome do evento, coisa que pode intrigar o leitor não envolvido com o universo esportivo. Além dela, as chamadas admitidas pelo projeto gráfico anunciam: + Cuba, + Lisboa/Portugal e + Colômbia.

\section{Considerações finais}

Partimos da premissa de que mais do que distrair o passageiro ao longo do processo muitas vezes exaustivo e comumente repleto de percalços de uma viagem de avião, as revistas de bordo engendram cenografias que projetam um ethos discursivo das marcas que representam para legitimar suas falas, visões de mundo, suas estratégias comerciais e, claro, propor uma ação para o consumo. O ethos "anfitrião", o mais identificável num primeiro momento, se revela de modo mais ou menos explícito nas duas revistas. Os efeitos de sentido dessa construção estão expressos nos enunciados assinados pelos executivos das duas marcas, no espaço do editorial e surgem, mais implicitamente, nas semânticas de sedução propostas pelos enunciados que interpelam o enunciatário a ingressar no mundo onírico das viagens e do turismo. O "anfitrião" é alguém que mobiliza os afetos da audiência, ao propor em meio a paisagens paradisíacas, um roteiro testado e aprovado para dar vazão aos seus desejos de escapismo e distinção social. Um mundo tematizado pela marca da companhia aérea que o transporta no instante em que tem contato com a revista e ao qual ela lhe dá acesso.

Na revista Vamos/Latam as evidências do ethos "anfitrião" são mais recorrentes e, em geral, estão associadas a outros ethé, como "o explorador", "o conquistador", ou "o que detém o mapa e os saberes", 
especialmente da América Latina, especialidade da Latam e sobre a qual ela constrói sua identidade de marca. Nota-se que nenhum destino turístico brasileiro é destacado nas capas das edições analisadas.

Na revista Gol, o ethos "cidadão engajado" entra em articulação com outros ethé: "o atualizado", "o aberto", "o politizado" para modular o tom com qual a marca busca interpelar seus enunciatários. Para analisar esse efeito de sentido, perpetrado pela revista Gol, voltamos aos ensinamentos de Lipovetsky (2007), com relação ao valor ético das trocas como instrumento de afirmação identitária dos neoconsumidores.

Essa construção de si, que se cristaliza nas páginas da Gol, não é feita no modo de um auto-elogio, mas é mostrada ora através de estereótipos, ora por via das pessoas que representam ali seus papéis sociais. "Toda forma de se expressar resulta de uma escolha entre várias possibilidades linguísticas e estilística", nos lembra Ruth Amossy (2005, p. 31). É então que a marca se dispõe a empunhar bandeiras de causas sociais, construindo seu ethos a partir de predicados de altruísmo e humanidade, buscando adesão na sensibilidade da audiência. Esse enunciador consciente problematiza questões de seu tempo, disposto a acolher um consumidor que se identifica com esses valores.

\section{Referências}

ALI, Fatima. A arte de editar revistas. São Paulo: Companhia Editora Nacional, 2009.

AMOSSY, Ruth. Imagens de si no discurso: a construção do ethos. São Paulo: Contexto, 2005.

ASSOCIAÇÃO BRASILEIRA DE EMPRESAS AÉREAS. Disponível em: https://www.abear.com.br/imprensa/dados-e-fatos/. Acesso em: 11 nov. 2019.

CHARAUDEAU, Patrick. Discurso das mídias. São Paulo: Contexto, 2015.

CHARAUDEAU, Patrick. Linguagem e discurso, modos de organização. São Paulo: Contexto, 2016.

FIORIN, José Luiz. As astúcias da enunciação: as categorias de pessoa, espaço e tempo. São Paulo: Contexto, 2016.

FISCHER, Andrea. Revista customizada: o jornalismo a serviço das fontes. Florianópolis: Combook, 2013. 
FOUCAULT, Michel. Arqueologia do saber. Rio de Janeiro: Forense Universitária, 2008.

GOL Linhas Aéreas. São Paulo: Trip, n. 178, jan. 2017.

GOL Linhas Aéreas. São Paulo: Trip, n. 183, jun. 2017. 156 p. Disponível em: https://www.voegol.com.br/pt/servicos-site/Magazine/revista GOL 183.pdf Acesso em: 21 fev. 2020.

GOL Linhas Aéreas. São Paulo: Trip, n. 184, jul. 2017. 81 p. Disponível em: https://www.voegol.com.br/pt/servicos-site/Magazine/revista GOL 184.pdf. Acesso em: 21 fev. 2020.

GOL Linhas Aéreas. São Paulo: Trip, n. 202, jan. 2019. 61 p. Disponível em: https://www.voegol.com.br/pt/servicos-site/Magazine/GOL 203 duplas.pdf. Acesso em: 21 fev. 2020.

GOL Linhas Aéreas. São Paulo: Trip, n. 208, jul. 2019. 71 p. Disponível em: https://www.voegol.com.br/pt/servicos-site/Magazine/GOL 208 Completo.pdf. Acesso em: 21 fev. 2020.

LIPOVETSKY, Gilles. A felicidade paradoxal: ensaio sobre a sociedade de hiperconsumo. São Paulo: Companhia das Letras, 2007.

MAINGUENEAU, Dominique. Análise de textos de comunicação. São Paulo: Cortez, 2002.

MAINGUENEAU, Dominique. Ethos, cenografia e incorporação. In: AMOSSY, Ruth. As imagens de si no discurso, construção do ethos. São Paulo: Contexto, 2005, p. 69-117.

MAINGUENEAU, Dominique. Cenas da enunciação. São Paulo: Parábola, 2008. MAINGUENEAU, Dominique. Discurso e análise do discurso. São Paulo: Parábola, 2015a.

MAINGUENEAU, Dominique. A propósito do ethos. In: MOTTA, Ana Raquel; SALGADO, Luciana (org.). Ethos discursivo. São Paulo: Contexto, 2015b, p. 11-29.

MARTINS, Ana Luiza. Revistas em revista: imprensa e práticas culturais em tempos de república, São Paulo (1890-1922). São Paulo: Edusp, 2008.

ORLANDI, Eni. Discurso e Texto: formação e circulação do sentido. Campinas: Pontes, 2001.

ORLANDI, Eni P. Análise de discurso: princípios e procedimentos. Campinas: Pontes Editores, 2009.

ORLANDI, Eni P. As formas do silêncio: no movimento dos sentidos.

Campinas: Editora da Unicamp, 2015.

PEREZ, Clotilde. Signos da marca: expressividade e sensorialidade. São Paulo: Cengage Learning, 2016.

SCALZO, Marilia. Jornalismo de revista. São Paulo: Contexto, 2011.

SEMPRINI, Andrea. A marca pós-moderna: poder e fragilidade da marca na sociedade contemporânea. São Paulo: Estação das Letras, 2010. 
SKYTRAX Worl Airline Awards. Disponível em:

https://www.worldairlineawards.com/2018-world-airline-awards-resultsannounced/. Acesso em: 10 fev. 2020.

TAVARES, Frederico; SCHWAAB, Reges (orgs.). A revista e o seu jornalismo. Porto Alegre: Penso, 2013.

VAMOS/LATAM. São Paulo: New Content, n. 9, jan. 2017. 172 p. Disponível em: https://issuu.com/spafax/docs/08-vamos latam enero 2017 web. Acesso em: 21 fev. 2020.

VAMOS/LATAM. São Paulo: New Content, n. 15, jul. 2017. 180 p. Disponível em: https://issuu.com/spafax/docs/vamos latam julio 2017 web Acesso em: 21 fev. 2020.

VAMOS/LATAM. São Paulo: New Content, n. 33, jan. 2019. 164 p. Disponível em: https://issuu.com/spafax/docs/vamos33 enero - issu. Acesso em: 21 fev. 2020.

VAMOS/LATAM. São Paulo: New Content, n. 39, jul. 2019. 156 p. Disponível em: https://issuu.com/spafax/docs/vamos39 julio - baja. Acesso em: 21 fev. 2020.

VAZ, Paulo; TRINDADE, Bernardo; COSTA, Vanessa. Capas de revista e seus leitores: um novo texto em cartaz. In: TAVARES, Frederico; SCHWAAB, Reges (org.). A revista e seu jornalismo. Porto Alegre, 2013.

VEBLEN, Thorstein. A Teoria da Classe Ociosa: um estudo econômico das instituições. São Paulo: Abril Cultural, 1983.

VILAS BOAS, Sergio. O estilo magazine: o texto em revista. São Paulo: Summus, 1996. 